\title{
Correction to: Enhancing Pharmacovigilance in Sub-Saharan Africa Through Training and Mentoring: A GSK Pilot Initiative in Malawi
}

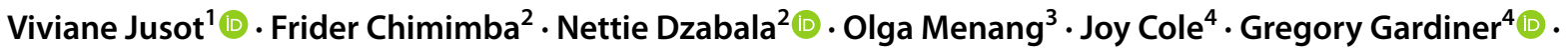 \\ Opokua Ofori-Anyinam ${ }^{1}$ (1) Olakunle Oladehin ${ }^{5} \cdot$ Cecilia Sambakunsi $^{6} \cdot$ Mphatso Kawaye $^{6}$. \\ Jens-Ulrich Stegmann ${ }^{1}$ (1) . Yolanda Guerra Mendoza ${ }^{1}$ (])
}

Published online: 31 March 2021

(c) The Author(s) 2021

\section{Correction to: Drug Safety (2020) 43:583-593 https://doi.org/10.1007/s40264-020-00925-4}

In the original publication, the reference number 32 text was incorrectly published and the correct reference is given below.

The incorrect reference number 32:

"Riders for Health. Welcome: Riders for Health Malawi. Moving global health forward; 2018. https://ridersintl.org/ malawi/. Accessed 28 Aug 2019."

The corrected reference should be:

"Riders for Health Malawi. Moving global health forward. https://www.riders.org/where-we-work/malawi/. Accessed 28 Aug 2019."

The original article can be found online at https://doi.org/10.1007/ s40264-020-00925-4.

Viviane Jusot

viviane.x.jusot@gsk.com

GSK, Wavre, Belgium

2 College of Medicine, University of Malawi, Blantyre, Malawi

3 PATH, Geneva, Switzerland

4 GSK, London, UK

5 GSK, Lagos, Nigeria

6 Pharmacy Medicines and Poisons Board, Lilongwe, Malawi

\begin{abstract}
Open Access This article is licensed under a Creative Commons Attribution-NonCommercial 4.0 International License, which permits any non-commercial use, sharing, adaptation, distribution and reproduction in any medium or format, as long as you give appropriate credit to the original author(s) and the source, provide a link to the Creative Commons licence, and indicate if changes were made. The images or other third party material in this article are included in the article's Creative Commons licence, unless indicated otherwise in a credit line to the material. If material is not included in the article's Creative Commons licence and your intended use is not permitted by statutory regulation or exceeds the permitted use, you will need to obtain permission directly from the copyright holder. To view a copy of this licence, visit http://creativecommons.org/licenses/by-nc/4.0/.
\end{abstract}

